\title{
Human Resource Management: Implications of Outsourcing in Public Organisations in Nigeria
}

\author{
${ }^{1 *}$ Andrew O. Suleman and ${ }^{2}$ Ogbette, Afamefuna Samuel \\ 1.Department of Political Science, University of Nigeria, Nsukka, Nigeria \\ 2.Department of Public Administration, University of Nigeria, Nsukka, Nigeria
}

\begin{abstract}
This article examined the implications of human resource management outsourcing in public organisations in Nigeria. The reviewed literature showed that the policy has positive and negative implications to the public organisations. In spite of the negative implications, human resource management outsourcing was increasing among the public organisations in Nigeria as the benefits were seen to out-weigh the negative implications. Management of the public organisations either partially or fully outsourced the management of some provided essential support services by the non-core grades of employees in the organisations. The management of the organisations adopted the policy essentially to cut cost on personnel maintenance and to also achieve service delivery of the out-sourced service(s). Žitkiene and Blusyt (2015) management model provide the theoretical explanation for the study.
\end{abstract}

Keywords: Human Resource Management, Implications, Outsourcing, Public Organisations, Nigeria

DOI: $10.7176 / \mathrm{PPAR} / 9-2-04$

\section{Introduction}

Public organisations in Nigeria have continued to witness various forms of policy reforms due to financial inadequacy, inefficiency and ineffectiveness that characterised their operations. Successive federal governments of Nigeria since 1988 when the policies of privatisation and commercialisation formally commenced (Idornigie, 2012) embarked on privatisation and commercialisation of public organisations as a remedy to the problems of financial inadequacy, efficiency, service delivery and overall operational standards of the organisations. For those that could not be privatised, the organisations management embarked on strategies to improve their financial inadequacy, efficiency and service delivery, hence, adoption of the policy of human resource management out-sourcing in public organisations.

Today, so many public organisations in Nigeria are outsourcing some of their operations which hitherto were part of the traditional functions that supported the organisations activities. Due to the need to cut cost and also improve the quality of service delivery, the management of some public organisations such as hospitals, tertiary institutions, the law courts among others, outsourced either partially or fully the management of some non-core grades of employees in areas like the security unit which covers security maintenance within the organisations, cleaning, clerical functions, canteen services, et cetera (Ikeije and Nwaoma, 2015).

Human resource management outsourcing in public organisations is a recent phenomenon in Nigeria, but it is not an unfamiliar phenomenon to some developed countries where outsourcing has been practiced for decades (Ikeije and Nwaoma, 2015). Today, many public organisations in Nigeria see human resource management outsourcing as a way out of the financial limitation which still remains the organisations main challenge. Notwithstanding this challenge, the organisations are increasingly under pressure to improve their administrative efficiency, effectiveness and to provide faster, better and more responsive services to their public. Given this scenario, some public organisations in their attempts to be frugal in expenditure embarked on human resource management outsourcing of non-core grades of staffs as an option in their efforts to cut costs, improve efficiency and service delivery (Sang, 2010). The growing use of human resource management outsourcing in public organisations reflects a general acceptance by the organisations administrators that it will reduce costs while continue to provide the essential services (Jefferies in Ikeije and Nwaoma, 2015).

It is on this background, that this paper seeks to examine the implications of outsourcing human resource management in the public organisations in Nigeria. This study was carried out reviewing the extant literature that relates to the issue in discourse.

\section{Literature Review}

The literature review was divided into the following subsections: theoretical model, brief conceptual clarification, human resource management outsourcing, human resource management outsourcing policy in the public organisations in Nigeria, implications of outsourcing human resource management in public organisations in Nigeria and conclusion.

\subsection{Theoretical Model}

To provide a theoretical explanation for human resource management outsourcing, Žitkiene and Blusyt (2015) 
theoretical model was adapted for this study. Žitkiene and Blusyt examined outsourcing models of some authors and derived management model for human resource outsourcing which they tested among service companies.

Researchers have produced models for different groups of services: information technology outsourcing (Robinson and Kalakota, 2004), logistics outsourcing (De Boer, Gaytan and Arroyo, 2006), human resource outsourcing (Lilly, Gray and Virick, 2005), business-processes outsourcing (Kim and Won, 2007) among others. Models can have a theoretical or practical nature and can be based on various approaches, including strategic management (Blumberg, 1998) and supply-chain management (De Boer et al., in Žitkiene and Blusyt, 2015).

Human-resource outsourcing is an innovative management strategy that focuses on all areas relating to human resources and their management. It can have both negative and positive implications on an organisation. Despite existing gaps and assessing the benefits, the use of human-resource management outsourcing is increasing. It is therefore, important to manage this activity properly, especially among service organisations for which the human factor is highly relevant (Žitkiene and Blusyt, 2015). Blumberg; Franceschini, Galetto, Pignatelli and Varetto in Žitkiene and Blusyt (2015) noted, that in making a decision with respect to outsourcing, it is necessary to analyse the organisation's internal and external environments. Žitkiene and Blusyt (2015) on their part examined that similar management functions and processes were seen to: identify core and non-core organisation's activities; decide which activities will be outsourced; analyse potential service providers and make contact with them; enter into a contract; and control outsourcing.

Blumberg; Mclvor; and Franceschini et al. in Žitkiene and Blusyt (2015) emphasized, that following the identification of core and non-core activities and assessing their performance at the organisation, non-core activities should be given to an external supplier. This requires analysis to reveal whether organisation employees or external providers can better perform an activity's main tasks. It is then necessary to analyse the providers in the market and possible methods of co-operation. The authors pointed out, that there are many ways to co-operate with external suppliers. The final step is to conclude a contract and monitor the execution processes (Žitkiene and Blusyt, 2015).

Human resource management outsourcing is a complex process that requires thorough study. The mere decision to use human resource outsourcing is a human resource management tool. Based on analysis of the examined outsourcing models, a management model for human resources outsourcing was composed (Žitkiene and Blusyt, 2015).

The model consists of three stages: planning and analysis, decision-making, and management. In the planning and analysis phase, it is necessary to consider all the benefits of this activity and what the organisation expects to achieve. Reasons for human resource management outsourcing can continuously vary because of a changing internal and external environment. Decision-making involves the implementation of certain steps that can help to find the optimal solution.

In the decision-making stage, generic decision-making steps were adopted that have been discerned in the analysis of outsourcing models. These should be the same regardless of the type of organisation or its activities. It is important to analyse the organisation's activities with regard to human resources (De Boer et al. in Žitkiene and Blusyt, 2015). However, when the decision to outsource is made, it is recommended that the opinion of researchers is relied on, such as Arias-Aranda, Bustinzab, and Barrales-Molinaa; Espino-Rodriguez and Padron-Robaina; Sani, Dezdar and sulaiman; Rahim and Baldry in Žitkiene and Blusyt (2015), who emphasized that organisations should use outsourcing for non-core activities.

In the third stage, it is important to monitor human-resource management outsourcing. Depending on the factors that have led to this type of outsourcing, evaluation criteria and management can vary and change in the organisation, depending on factors such as time, cost, efficiency and flexibility. Organisations need to examine whether they have achieved an expected benefit, otherwise, earlier stages should be reviewed and new decisions made. This stage is influenced by earlier phases and only the specifics of each organisation determine which indicators will be used and how human resource management outsourcing will be assessed and managed (Žitkiene and Blusyt, 2015).

\section{Conceptual Clarification}

The concepts of human resource management and human resource management outsourcing were briefly reviewed as conceptualized by some authors but in similar ways to provide understanding of the discourse.

\subsection{Human Resource Management}

Human resource management encompasses those activities designed to provide for and coordinate the human resources of an organisation (Ikeanyibe in Onyishi, Eme and Emeh, 2012). According to Frank in Onah (2014) human resource management is a series of activities in which the job, the individual and the organisation all interact as each develops and changes. Similarly, Griffin in Onah (2014); and Onyishi, Eme and Emeh (2012) see human resource management as the set of organisational activities directed at attracting, developing and 
maintaining an effective workforce.

On their part, Okafor (2012); Ayesha, Nosheen and Reema in Gaafar (2012) were of the view, that human resource management is the function within an organisation that focuses on recruitment of, management of, and providing direction for the people who work in the organisation. Thus, human resource management is the organisational function that deals with issues related to people such as hiring, compensation, performance management, organisation development, safety, wellness, benefits, employee motivation, communication, administration, and training. To Armstrong; Lyton and Pareek in Okafor (2012) human resource management is also a strategic and comprehensive approach to managing people and the workplace culture and environment. Effective human resource management according to them therefore, enables employees to contribute effectively and productively to the overall organisational direction and the accomplishment of the organisation's goals and objectives.

From the above definitions, there is no doubt, that human resource management in the context of public administration in Nigeria involves so much of public organisations financial resources and management of the employees work behaviour for delivery. Thus, the need to find ways to reduce cost of human resource management services and also achieve service delivery especially with the non-core grades of employees.

\subsection{Human Resource Management Outsourcing}

Similar definitions have been offered by scholars in explaining the concept of outsourcing in relation to human resource management. According to Reed (2001); Irefin, Olateju and Hammed (2012) human resource management outsourcing is a process of replacement of in-house provided activities by contracting it out to external agents. In other words, it is a system where organisations give out some function(s) performed by internal staffs to outside service providers to handle on their behalf. Similarly, Simmonds and Gibson in Stasiulyte (2011, p.117) opined, that human resource management outsourcing services as "specific clearly defined transfer of activity to external company". It means that the aim of this function or essence is transferred or sold to the third part.

In the context of this paper, drawing from the above definitions, human resource management outsourcing refers to the partial or full transfer of human resource management to external service providers who then owns, manages and administers for the provision of selected service(s) based on defined performance service level agreement by the management of an organisation.

\section{Human Resource Management Outsourcing Policy in the Public Organisations in Nigeria}

Human resource management outsourcing in the public sector has remained low and inadequate since the $1970 \mathrm{~s}$ due to ministries, departments and agencies poor support of the human resource management outsourcing market (Okorie, 2010). Human resource management outsourcing, a component of outsourcing policy in the public sector in Nigeria became pronounced with the re-introduction of the privatisation and commercialisation polices in 1999; and the introduction of monetisation policy in 2003.

According to Ikeije and Nwaoma (2015) the first phase of human resource management outsourcing policy in the public sector was introduced by the Federal Government of Nigeria who funds the public organisations at the federal level. The policy made it clear that all Grade-1 jobs in the Federal Public Service should be outsourced (Ikeije and Nwaoma, 2015). The implication of this policy was the outsourcing of cleaning jobs, messenger job, attendants, security jobs within the organisation, et cetera. Although these jobs categories are not specialised ones, but they have been deregulated as government is no longer willing to fund them directly. However, many of the public organisations did not find it easy (such as the public universities) implementing this policy. But the first function that many public organisations outsourced were catering, cleaning and security services (Ikeije and Nwaoma, 2015).

Human resource management functions may be partially or fully outsourced. The distinction between the two is that in the former, the organisation retains some control over the outsourced functions and may share access to information with the vendor. In the latter, the organisation relies upon the vendor to carry out the entire function. Thus, the human resource management department's role with regard to the outsourced function is minimal and may be limited only to managing the relationship with the vendor (Žitkiene and Blusyt, 2015; www.shrm.org/research).

\section{Implications of Human Resource Management Outsourcing in Public Organisations in Nigeria}

In many of the public organisations in Nigeria, human resource management outsourcing has become the order of the day as the managements find the system cost effective in terms of personnel cost for their organisations. According to Okorie (2010, p.26) "human resource management outsourcing in the public sector organisations is still evolving". He further opined that outsourcing as a management tool for restructuring and refocusing human resource management in public organisations; it challenges the managements to build flexible organisations centered on the core competencies and activities for which they were established for. In making this strategic 
decision, public organisations gain more by outsourcing non-core human resource grades normally maintained in-house to a qualified vendor or service provider. This is usually for a specified period of time and at a negotiated fee, in accordance with stipulated terms of service level agreement (Okorie, 2010).

Human resource management outsourcing in public organisations results in cost saving in terms of overhead reduction, staffing flexibility, development of in-house staff, et cetera. It also result in the shedding of non-core corporate activities and right focusing of valuable material and core human resources on core activities, thereby repositioning the organisations for efficiency and effectiveness (Babu, 2005; Leavy in Okorie, 2010; Behara, Copozzoli and Gundersen in Adegbami, Makinde and Shiyanbade, 2014). Okorie (2010) added that human resource management outsourcing engagement in public organisations is extending beyond cost savings to increasing perception as a strategic tool for achieving high performance, and forcing change in human resource practices with tremendous strategic values to the organisations.

Wills (2014) observed that, in the challenging economic circumstances, public organisations have chosen to adopt the dominant business model by subcontracting their low wage routine work to a variety of cleaning, catering and security firms. The argument was that, this allows shedding unnecessary costs and responsibilities of employing many hundreds of workers. Adegbami, Makinde and Shiyanbade (2014) were of the same view, that human resource management outsourcing helps in cutting down on staff maintenance costs; thus, public organisations save a lot of money through contracting jobs to outsourced staff. The organisations thereby relieve themselves of complications involved in maintaining certain grades of internal human resources. Similarly,

Manisha and Deepa (2011) noted, that human resource management outsourcing in public organisations is also seen as an effective way to by-pass organisational politics; improve efficiency, service delivery, save money and free time for core functions. In the same vein, Elmuti in Fapohunda (2013) identifies implications of outsourcing human resource management in public organisations to: reduce cost, improve quality service, making financial resources available for capital projects and focusing on core competencies. In allusion Smith, Vozikis and Varaksina in Stasiulyte (2011) emphasized, that outsourcing of human resource management services can affect not only expenses but also organisation's capability to service clients with quality. So, organisation can choose human resource management services in order to achieve added value. Brewster corroborated the above views that, it is all about "finance-driven idea" connecting human resource management to outsourcing-the idea that public organisations can save a lot of money by outsourcing certain non-core categories of human resource management (Brewster in Manisha and Deepa, 2011; Fapohunda, 2013).

It was acknowledged that, while human resource management outsourcing policy has positive implications it also have untended negative implications in public organisations. As the organisations relinquish control, it makes most workers less invested in the organisations. For there is no emotional attachment to the organisations work (Ikeije and Nwaoma, 2015). Anyim, Ikemefuna and Mbah (2011) argued, that from experience permanent employees who have stake in the organisations show more commitment to their jobs than the contract employees supplied by vendors. According to them, human resource managers should examine the cost-benefit implications of outsourcing certain human resource management services vis-à-vis engaging employees on permanent basis.

Ikeije and Nwaoma (2015) noted, that the human resource management outsourcing policy though, has been justified on the basis of the benefits it delivers to public organisations in terms of budget control, concentration on core service delivery, use of specialized personnel; risk sharing, internal resource availability, et cetera. However, there is the threat by the host communities of some public organisations like the tertiary institutions whose members are affected by the human resource management outsourcing policy. According to them, some public tertiary institutions which desired to outsource its human resource management in charge of security function in the institutions expressed double feelings regarding the sociological implications of disengaging the existing staff that were predominantly from the host communities. If the institutions decide to outsource its human resource management function, especially the non-core grades of employees they will be accused of abandoning their corporate social responsibility to the indigenes who have sacrificed their land to the institutions (Ikeije and Nwaoma, 2015).

Ikeije and Nwaoma (2015) further argued, that according to some authors it has been observed that outsourcing traditional human resource management in public organisations will widen inequalities within the organisations; inequalities between its different categories of staff-as well as creating organisations that produces good jobs for some and bad jobs for others; primarily those from the communities in which the public organisations like the tertiary institutions are located.

\section{Conclusion}

The trend towards outsourcing human resource management for certain functions in public organisations in Nigeria has shown to impact the organisations more positively as it majorly cut costs on staff maintenance in terms of salaries, wages and fringe benefits (leave bonus, pension, social insurance, et cetera) and also achieve service delivery of out-sourced services for effective functioning of the organisations. But this is not without engaging the services of competent service providers and the public organisations top management commitment 
to the policy; the adapted theoretical model that provided the theoretical explanation affirmed this. In spite of the positive implications of human resource management outsourcing to the public organisations, it is not without negative implications which the organisations should manage well.

\section{References}

Adegbami, A., Makinde, O. and Shiyanbade, B. (2014) 'Human resources outsource in Nigeria: Exploiting organisation vital tools', International Journal of Humanities and Social Science, 4(13), pp. 131-135.

Adeyemi, S. L. and Salami, A. O. (2008) 'An outsourcing perspective of planning and control in industrial networks', International Business Management, 2(3), pp. 97-102.

Anyim, F. C., Ikemefuna, C. O. and Mbah, S. E. (2011) 'Human resource management challenges in Nigeria under a globalised economy', International Journal of Economics \& Management Sciences, 1(4), pp. 01-11. Available at: http://www.managementjournals.org (Accessed: 4 May, 2017)

Babu, M. (2005) 'Myth: All outsourcing is offshoring'. Available at: http://www.computerworld.com (Accessed: 7 June, 2017)

Fajana, S., Owoyemi, O., Elegbede, T. and Sheriff, M. G. (2011) 'Human resource management practices in Nigeria', Journal of Management and Strategy, 2(2), pp. 57-62. Available at: http://www.sciedu.ca/jms (Accessed: 4 May, 2017)

Fapohunda, T. M. (2013) 'Towards successful outsourcing of human resource functions', International Journal of Human Resource Studies, 3(3),pp. 39-49. Available at: http://www.macrothink.org/ijhrs (Accessed: 4 May, 2017)

Gaafar, M. A. (2012) 'The impact of human resource management practices on organizational performance in Saudi banking sector', European Journal of Business and Management, 4(21), pp. 188-196. Available at: http://www.iiste.org (10 March, 2017)

Idornigie, P. O. (2012) 'Privatization and commercialization of public enterprises in Nigeria', law and economic transformation in Nigeria. Ilfe-Ife, Nigeria, 11-13 July. Ilfe-Ife: Faculty of Law, Obafemi Awolowo University. Available at: http://www.paulidornigie.org (Accessed: 10 March, 2017)

Ikeije, U. U. and Nwaoma, P. C. (2015) 'The outsourcing policy in the Nigerian public universities: Issues and Challenges', EPRA International Journal of Economic and Business Review, 3(2), pp. 167-172.

Irefin, I. A., Olateju, O. I. and Hammed, G. O. (2012) 'Effect of outsourcing strategy on project success', Transnational Journal of Science and Technology, 2(6), pp. 128-143.

Manisha, S. and Deepa, S (2011) 'Human resource outsourcing: Analysis based on literature review', International Journal of Innovation, Management and Technology, 2(2), pp. 127-135.

Neo, R. A., Hollenbeck, J. R., Gerhart, B. and Wright, P. M. (2003) Human resource management: Gaining a competitive advantage. New York: McGaw-Hill/Irwin.

Okafor, E. E. (2012) 'Emerging nonstandard employment relations and implications for human resource management functions in Nigeria', African Journal of Business Management, 6(26), pp. 7612-7621. Available at: http://www.academicjournals.org/AJBM (Accessed: 4 May, 2017)

Okorie, N. E. (2010) 'Challenges of human resource outsourcing in Nigerian public sector organisations: Issues and prospects', Journal of Business and Organisational Development, 2, pp. 25-36. Available at: http://www.cenresin.org (Accessed: 17 March, 2017)

Onah, F. O. (2014) Human resource management. 3rd edn. Nsukka: University of Nigeria Press.

Onyishi, A. O., Eme, O. I., and Emeh, I. E. J. (2012) 'Problems of personnel management in Nigeria: The Nigerian local government system experience', Arabian Journal of Business and Management Review (OMAN Chapter), 1(6), pp. 36-49.

Reed, A. (2001) Innovation in human resource management: Tooling up for the talent wars. London: CIPD house.

Sang, J. K. (2010) 'Outsourcing in Kenyan universities: An examination of challenges and opportunities', International Journal of Business and Social Sciences, 1(2), pp. 204-212.

Society for Human Resource Management (2004) Human resource outsourcing survey report. Available at: http://www.shrm.org/research (Accessed: 10 March, 2017)

Stasiulyte, E. (2011) 'Motives of human resource management outsourcing: A case study from Lithuania', Economics and Sociology, 4(1), pp. 116-125.

Wills, S. (2014) Outsourcing can save money, but squanders universities morale. Available at: http://www.theguardian.com/higher-education-network/efficiencyexchangepartner (Accessed: $10 \mathrm{March}$, 2017)

Žitkiene, R. and Blusyt, U. (2015) 'The management model for human resource outsourcing among service companies', Intellectual Economics 9, pp. 80-89. Available at: www.sciencedirect.com(Accessed: 2 April, 2017) 